\title{
DESENTRALISASI WISATA RELIGI INDONESIA MELALUI CITY BRANDING WISATA KABUPATEN BANGKALAN MADURA
}

\section{Decentralization of Indonesian Religious Tourism Trough City Branding of Bangkalan Madura Regency}

\author{
Farida $^{1}$, Zulaikha ${ }^{2}$, Hartopo Eko Putro ${ }^{3}$ \\ ${ }^{122) 3)}$ Dr. Soetomo University, Indonesia \\ Jalan Semolowaru No. 84 Surabaya
}

Diterima 29 Mei 2020 / Disetujui 29 September 2020

\begin{abstract}
Bangkalan people are attached to Islamic culture. Their daily life is influenced by Islamic teachings and is evident in their social behavior, including in the arts and seeking solace. One of the consolations known in the community is to travel. Of course, Islamic travel and does not violate Islamic law. For the people of Bangkalan, the pilgrimage to the tombs, in addition to being one of the rituals believed to seek blessings, is also a place to tour. Therefore, the pilgrimage to the graves of scholars and community leaders in Bangkalan becomes a sight that can be seen every day. Religious tourism then developed into an opportunity in the development and improvement of people's welfare. Unfortunately, this has not yet become the focus of interest of the Bangkalan district government. Though building city branding as a religious tourism destination opens up opportunities for Bangkalan to compete with other regions in getting tourist visits. This study tries to identify the problem of tourism development and produce output in the form of religious tourism branding draft for Bangkalan district. The method used is observation and in-depth interviews. Although the results of this study indicate that the Bangkalan district is not ready to build a religious tourism brand, but the data obtained in the field shows that Bangkalan has a lot of religious tourism potential. The results of this study are expected to be input for the district government, scholars and tourism stakeholders. Further hope is to be able to help the Bangkalan district government to build city branding and create marketing communication concepts for their region.
\end{abstract}

Keywords: branding; tourism; religious; Bangkalan

\begin{abstract}
ABSTRAK
Masyarakat Bangkalan lekat dengan kultur Islam. Kehidupan keseharian mereka dipengaruhi ajaran Islam, termasuk dalam berkesenian dan mencari penghiburan. Salah satu penghiburan yang dikenal dalam masyarakat adalah melakukan perjalanan wisata. Tentu perjalanan wisata yang Islami dan tidak melanggar syariat Islam. Bagi masyarakat Bangkalan, ziarah ke makam, selain menjadi salah satu ritual yang dipercayai untuk mencari berkah, juga menjadi ajang berwisata. Karena itu, ziarah ke makam-makam ulama dan tokoh masyarakat di Bangkalan menjadi pemandangan yang bisa dilihat setiap harinya. Wisata religi kemudian berkembang menjadi satu peluang dalam pembangunan dan peningkatan kesejahteraan masyarakat. Sayangnya, hal ini belum menjadi focus of interest pemerintah kabupaten Bangkalan. Padahal membangun city branding sebagai destinasi wisata religi membuka kesempatan bagi Bangkalan untuk bersaing dengan wilayah lain dalam mendapatkan kunjungan wisatawan. Penelitian mengidentifikasi problema pembangunan wisata dan menghasilkan output berupa draft branding wisata religi untuk kabupaten Bangkalan. Metode yang digunakan adalah observasi dan wawancara mendalam. Meskipun hasil penelitian ini menunjukkan bahwa kabupaten Bangkalan belum siap membangun brand wisata religi, tetapi data yang diperoleh di lapangan menunjukkan bahwa Bangkalan punya banyak potensi wisata religi.
\end{abstract}

Kata Kunci: branding; wisata; religi; Bangkalan

*Korespondensi penulis:

Email: zulaikha@unitomo.ac.id

PENDAHULUAN 
Jika ingin mengetahui destinasi wisata di Bangkalan Madura dari mesin pencari di internet, akan terlihat bahwa tempat teratas diduduki oleh Bukit Jaddih, galian bukit kapur yang kemudian menjadi trending topic di media sosial karena foto-fotonya banyak diunggah para netizen.

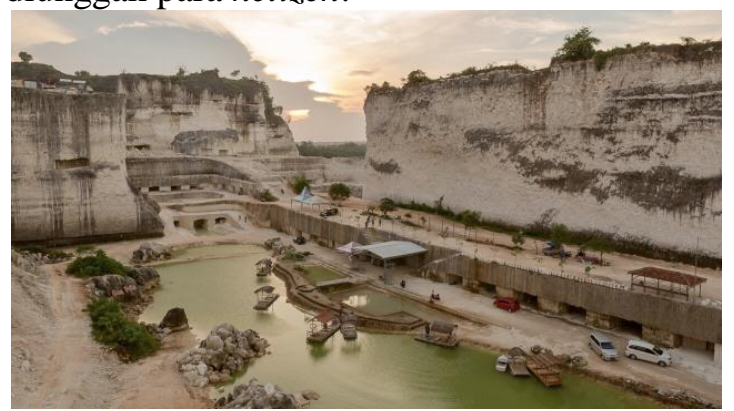

Gambar 1. Bukit Jaddih

Sumber: (Kumparan, 2018)

Produk yang dihasilkan setiap daerah, seperti Hoba Pojo yang merupakan kain tradisional dari kabupaten Nagekeo, Nusa Tenggara Timur yang merupakan ciri khas daerah (Susilo, Putranto, Neu, \& Navarro, 2020). Demikian juga dengan kuliner. Makanan khas daerah Bangkalan pun bisa dengan mudah ditemukan di mesin pencari, dan yang muncul paling pertama adalah makanan Bebek Sinjay, merujuk pada rumah makan bebek goreng dengan nama yang sama.

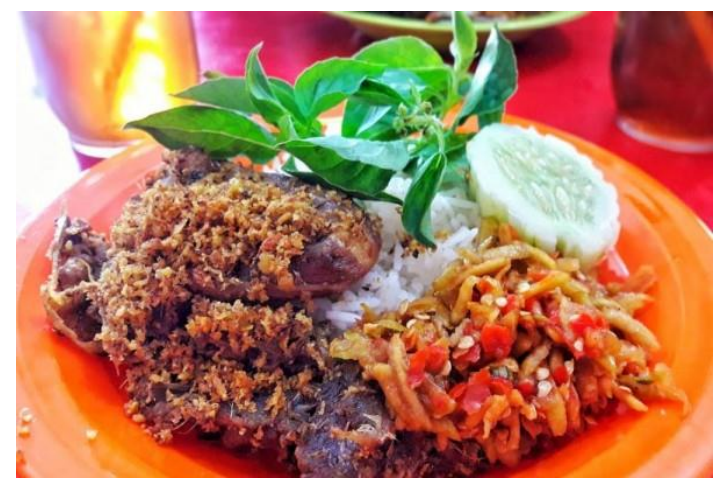

Gambar 2. Bebek Sinjay

Sumber: (Deviana, 2019)

Kabupaten Bangkalan merupakan salah satu kota yang dekat dengan Surabaya. Meski begitu, pengunjung dari luar provinsi yang datang ke Surabaya baik untuk bisnis maupun wisata, biasanya memilih pergi ke Malang dan Batu untuk menikmati liburan. Malang dan Batu memang dikenal memiliki banyak destinasi wisata. Padahal, dibandingkan ke Malang dan Batu yang berjarak sekitar 100 km, Bangkalan jauh lebih dekat dan bisa ditempuh dengan waktu yang relatif lebih pendek.

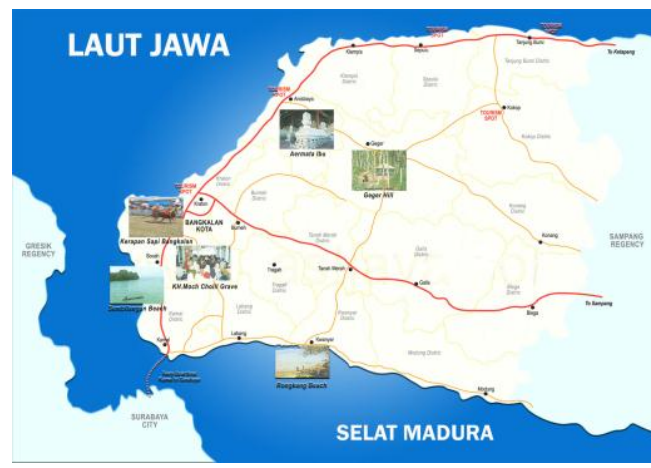

Gambar 3. Peta Bangkalan Sumber: (SNC, 2020)

Jembatan Suramadu, jembatan di atas laut pertama di Indonesia yang menghubungkan Surabaya-Madura merupakan pintu masuk yang punya daya tarik tersendiri.

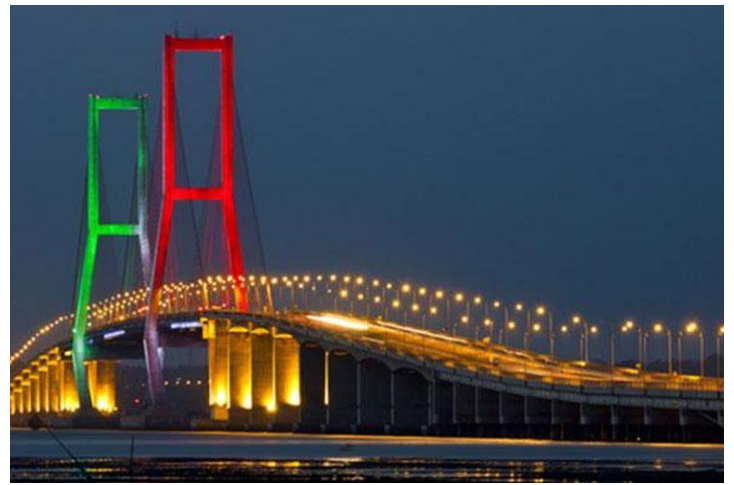

Gambar 4. Jembatan Suramadu

Sumber: (Prabowo, 2018)

Dibandingkan dengan Malang dan Surabaya yang sudah mempunyai city branding, Bangkalan sampai saat ini belum dikenal mempunyai pencitraan kota. Sejak pariwisata dijadikan prioritas pembangunan dalam pemerintahan Presiden Joko Widodo, kota-kota di Indonesia kemudian seperti berlomba membuat pencitraan kota yang bernuansa lokal-global, seperti Never Ending Asia (Yogyakarta), The Spirit of Java (Solo), Sparkling Surabaya, Shinning Batu, dan sebagainya. Salah satu fungsi city branding adalah menjadi salah satu strategi komunikasi pemasaran pariwisata.

Pariwisata menjadi leading sector dalam pembangunan, kesejahteraan dan kebahagiaan. Hal itu disebabkan karena pariwisata: 
- Menjadi salah satu sumber pendapatan dalam ekspor, membuka lapangan kerja, dan pengembangan usaha serta infrastruktur

- Merupakan salah satu bagian dari sektor ekonomi terbesar serta tercepat pertumbuhannnya (Ratman, 2016).

City branding diyakini memiliki kemampuan untuk mengubah pandangan seseorang terhadap suatu kota, dan berupaya untuk melihat perbedaan kemampuan suatu kota dari kota lain. Ini merupakan upaya untuk memasukkan konsep branding suatu wilayah. Tujuan branding kota mungkin berbeda, seperti menarik wisatawan, investor, warga baru, dan orang-orang berbakat (Rafa'al, 2017; Winarti, 2017). City branding diyakini memiliki kemampuan untuk mengubah pandangan seseorang terhadap suatu kota, dan berupaya untuk melihat perbedaan kemampuan suatu kota dari kota lain. Ini merupakan upaya untuk memasukkan konsep branding suatu wilayah. Tujuan branding kota mungkin berbeda, seperti menarik wisatawan, investor, warga baru, dan orang-orang berbakat.

Dalam kasus gagasan merek pariwisata, yang memiliki kemampuan untuk memperkenalkan otonomi daerah dan tren globalisasi baru yang lazim, daerah juga harus bertujuan untuk menangkap pasar, khususnya wisatawan dan investor, di daerahnya masingmasing. Daerah juga membutuhkan merek yang kuat. City Brand, menurut definisi, adalah identifikasi, lambang, logo, atau merek dagang yang melekat pada suatu wilayah. Pemerintah daerah tentunya harus menciptakan brand untuk daerahnya sesuai dengan kapasitas dan positioning daerahnya (Riyadi, Susilo, Armawati Sufa, \& Dwi Putranto, 2019; Susilo \& Primatama, 2018).

Tempat atau posisi dapat diberi nama yang kemungkinan besar berasal dari nama daerah yang sebenarnya. Tujuan dari membandingkan lokasi geografis / kota adalah untuk membuat orang sadar atau sadar akan keberadaan lokasi tersebut dan kemudian menciptakan keinginan untuk menghubungkannya. Tujuan dari branding suatu kota atau tempat adalah membangun visibilitas dan citra yang bersahabat terhadap suatu tempat sehingga menarik kunjungan dari individu maupun pelaku bisnis (Keller, Parameswaran, \& Jacob, 2011).

Proses City Branding berkaitan dengan penciptaan Identitas Kota yang menunjukkan perbedaan dan panduan bagaimana Kota dipasarkan. Kota dengan identitas yang kuat juga bisa menjadi kota dengan gambaran yang kuat. Pencarian identitas merupakan langkah pertama yang harus dilakukan dalam pembuatan citra kota. Identitas dalam membentuk citra kota tidak datang dengan sendirinya, tetapi harus diupayakan, diputuskan, dan ditangani sedemikian rupa sehingga merek suatu kota menjadi penanda identitas (Yananda \& Salamah, 2014).

City branding dapat dikatakan sebagai mode komunikasi gambar yang melibatkan tiga aspek komunikasi yaitu komunikasi primer, komunikasi sekunder, dan komunikasi tersier. Kontak primer adalah semua impian kota, seperti strategi lanskap, infrastruktur, administrasi, dan semua aktivitas atau tindakan yang relevan dengan kota. Dalam pelaksanaannya, branding termasuk menghubungkan berbagai pihak dengan gambaran yang ingin dibuat kota. Komunikasi sekunder adalah komunikasi terstruktur dan intens yang dikenal luas dalam praktik pemasaran seperti periklanan, hubungan masyarakat, desain grafis, dll. Komunikasi tersier terkait dengan mulut ke mulut, yang diperkuat oleh media dan komunikasi pesaing, yang tidak dapat diatur oleh pengiklan . Tujuan dari keseluruhan proses branding dan dua jenis komunikasi yang diatur adalah untuk menghasilkan dan meningkatkan komunikasi tersier yang positif; Apalagi bagi warga perkotaan yang sekaligus menjadi target audiens paling relevan sekaligus pemasar perkotaan (Kavaratzis, 2004).

City branding biasanya menitikberatkan pada pengelolaan citra, tepatnya apa dan bagaimana citra tersebut dibuat serta aspek komunikasi yang dilakukan dalam proses pengelolaan citra. City branding juga merupakan tanggung jawab dan kemitraan semua pemangku kepentingan yang terhubung dengan kota. Tanggung jawab atas keefektifan branding kota dapat ditemukan di publik internal kota, di pemerintah kota, sektor swasta, pengembang, kelompok kepentingan, dan penduduk lokal. Dalam city branding, yang diprioritaskan adalah memanfaatkan seluruh 
potensi kota agar bernilai dan bermanfaat (Eushuis \& Klijn, 2010).

Sebagai kota yang dekat dengan ibukota propinsi, Bangkalan sesungguhnya punya beberapa obyek wisata yang bisa dikelola dan dijadikan unggulan produk pariwisatanya. Sayangnya, sampai saat ini, pariwisata belum menjadi unggulan, dan belum ada Perda yang mengaturnya. Bangkalan bisa dikatakan merupakan daerah tertinggal karena belum ada yang bisa ditonjolkan atau belum punya ciri khas. Meski begitu, Bangkalan sendiri sebetulnya sudah mempunyai slogan, yakni kota Dzikir dan Sholawat. Slogan itu kemudian mendasari munculnya wacana wisata syariah untuk kota Bangkalan, bahkan DPRD kabupaten Bangkalan kemudian berinisiatif menyusun Perda tentang Pariwisata Syariah. Selain karena alasan bahwa saat ini tidak banyak wilayah di Indonesia yang mengembangkan konsep wisata syariah selain Aceh, juga karena sesuai dengan adat dan budaya masyarakat.

Penelitian ini ingin membantu Bangkalan untuk menemukan city branding, sehingga bisa meningkatkan perolehan Pendapatan Asli Daerah (PAD)-nya dari sisi pariwisata. Mengapa pariwisata? Karena pariwisata di Bangkalan, tanpa dikelola secara profesional pun sudah berjalan dengan sendirinya, terutama wisata religi. Menurut Chotib, wisata iman merupakan pengalaman religi yang ditujukan untuk memuaskan kelaparan spiritual, agar jiwa yang kering kembali basah oleh hikmah ajaran agama (Chotib, 2015). Oleh karena itu, obyek wisata religi memiliki jangkauan yang sangat luas, mencakup lokasi mana saja yang dapat menawarkan suasana religiusitas kepada pengunjung dan menambah wawasan serta pengalaman spiritual. Religi atau keagamaan merupakan sebuah sistem kebudayaan. Bahkan wisata religi di Bangkalan belum pernah dipromosikan sampai saat ini, tetapi selalu didatangi oleh wisatawan lokal setiap harinya. Karena itu, membuat city branding berdasarkan wisata religi menjadi salah satu alternatif pilihan bagi kabupaten Bangkalan untuk menunjukkan eksistensinya, sekaligus bisa meningkatkan kesejahteraan masyarakatnya (Syam, 2005).

Terkait dengan city branding dan wisata religi ini, beberapa penelitian pernah dilakukan dengan kajian yang berbeda-beda. Kajian pengaruh pertumbuhan wisata religi di Makam Sunan Maulana Malik Ibrahim terhadap kehidupan sosial ekonomi masyarakat lokal. Dalam penelitian tersebut ditemukan bahwa telah dilakukan pemugaran makam dan gapura makam pada makam Sunan Maulana Malik Ibrahim dengan alasan pariwisata. Pemugaran itu semata-mata didasarkan pada alasan agar makam Sunan Maulana Malik Ibrahim itu berkembang menjadi destinasi wisata. Perkembangannya bahkan dinilai cukup pesat karena sudah dikelola secara profesional dengan Standar Operational Procedure yang dalam manajemennya. Temuan lain dalam penelitian ini, setelah pariwisata berkembang maka ada peningkatan pada masyarakat di bidang keterampilan pembuatan souvenir, dan munculnya usaha rumahan yang menyerap banyak tenaga kerja. Dengan demikian pemugaran makam demi menjadi destinasi wisata telah meningkatkan kesejahteraan masyarakat sekitarnya (Anwar, Hamid, \& Topowijono, 2017).

Annisarizki \& Sucahya, (2018) juga pernah meneliti manajemen wisata religius kesultanan Banten. Penelitian ini berfokus pada bauran kontak pemasaran yang diadopsi oleh kedua pemangku kepentingan untuk memaksimalkan jumlah pengunjung. Hasil penelitian ini menunjukkan bauran komunikasi pemasaran (aspek filosofis, keterkaitan antar unit kerja, penggabungan fungsi yang berbeda dan peningkatan loyalitas konsumen) yang diperkenalkan oleh pengelolaan wisata religi Kesultanan Banten belum terintroduksi secara optimal. Iklan, promosi pasar, humas dan personal sale telah dilakukan oleh Dinas Pariwisata Provinsi Banten, Dinas Olahraga dan Pariwisata Pemuda Kota Serang dan Organisasi Stakeholder Adat Kesultanan Banten. Periklanan, promosi penjualan dan hubungan masyarakat dilakukan dalam skala nasional melalui periklanan di surat kabar nasional, melalui partisipasi dalam pameran budaya nasional dan dengan berpartisipasi dalam kegiatan Kementerian Pariwisata. Peran humas adalah untuk melibatkan media nasional dalam publikasi kegiatan Gubernur Banten dalam setiap operasi di Kesultanan.

Sementara itu, masih menurut penelitian Annisarizki, kondisi dari Masjid Agung Banten Lama sendiri belum mencerminkan 
standarisasi objek wisata nasional, karena lingkungannya yang masih kumuh, kotor, banyak pengemis, adanya pungutan parkir liar, dan akses jalan yang belum memadai. Ini merupakan bukti jika manajemen pengelola kesultanan Banten belum menjalankan praktik bauran komunikasi pemasaran dengan optimal. Rencananya, jika revitalisasi kawasan Banten Lama sudah selesai di tahun 2020, maka pengelola akan menggunakan strategi komunikasi pemasaran dengan maksimal.

Pulau Madura sendiri juga pernah menjadi obyek penelitian oleh peneliti dari Universitas Trunojoyo Madura (Rachmad, 2017). Dalam hal ini Rachmad meneliti strategi branding wisata syariah pulau Madura. Ia menemukan hasil bahwa ada 2 wisata syariah di Madura yakni ziarah dan sejarah Islam. Kedua jenis wisata ini sama-sama berkembang tidak hanya di Bangkalan tetapi juga di semua kabupaten di pulau Madura yakni Sampang, Pamekasan dan Sumenep.

Beda dengan budaya, simbol dalam agama dianggap sakral. Simbol-simbol sakral tersebut kemudian diintegrasikan ke dalam sistem nilai dan kepercayaan yang dianut oleh masyarakat, dan disebut sebagai tradisi agama. Simbolisasi dalam kesenian Reog misalnya membentuk makna dan nilai dalam masyarakat. Berbeda dengan masyarakat, ikon dalam agama dianggap sakral. Benda-benda sakral ini kemudian dimasukkan ke dalam sistem prinsip dan kepercayaan yang dianut masyarakat, dan disebut sebagai praktik keagamaan. Simbolisasi dalam seni reog, misalnya membentuk makna dan nilai dalam masyarakat (Yurisma \& Bahruddin, 2020). Setiap praktik keagamaan memiliki simbol sakral. Orang-orang kemudian dapat melakukan sejumlah amalan untuk menjalankan amalan keagamaan. Salah satu tradisi keagamaan adalah ziarah ke makam.

Pada mulanya, ziarah ke makam adalah sebuah tradisi keagamaan. Makam yang diziarahi bukan hanya makam-makam leluhur, kyai dan orang yang dianggap penting yang ada dekat dengan tempat tinggalnya, tetapi mereka rela melakukan perjalanan jauh ke makam-makam yang jauh letaknya dari tempat tinggalnya. Perkembangannya kemudian, melakukan ziarah ke makam itu menjadi sebuah perjalanan wisata juga, karena tempatnya yang jauh tadi. Jadi wisata religi ini merupakan perjalanan dalam rangka melakukan tradisi keagamaan. Secara langsung maupun tidak langsung city branding memiliki pengaruh terhadap pengambilan keputusan wisatawan yang hendak mengunjungi suatu obyek wisata daerah. Mengingat tujuannya untuk mempromosikan pariwisata di suatu daerah maka city branding harus dibuat sesuai dengan kondisi di lapangan. Tetapi wisata religi yang dimaksudkan dalam penelitian ini yaitu wisata yang dilakukan dengan melakukan ziarah ke makam tokoh-tokoh baik tokoh agama atau tokoh masyarakat lainnya.

Dalam Islam, ziarah kubur dianggap sebagai perbuatan sunah, dikerjakan berpahala, tak dikerjakan pun tak apa. Praktik ziarah sebetulnya telah ada sebelum Islam, tetapi dilebih-lebihkan, sehingga sempat dilarang oleh Nabi Muhammad SAW. Tetapi, tradisi ini dihidupkan kembali setelah umat Islam menjadi kuat di Makkah, bahkan dianjurkan, tujuannya agar manusia yang berziarah selalu ingat akan kematiannya sehingga akan berbuat baik pada saat hidupnya (Arifin, 2007).

Ada 19 manfaat wisata religi menurut Maya Tirta Sari (Sari, 2016), yakni yakni (1) melepas kejenuhan, (2) menghilangkan beban pikiran dan stres, (3) menyegarkan dahaga spiritual, (4) mengingatkan manusia pada akhirat, (5) lebih dekat dengan Tuhan, (6) menambah wawasan, (7) meningkatkan kualitas pribadi, (8) bersosialisasi lebih baik, (9) mendapatkan zona nyaman yang berbedabeda, (10) meningkatkan percaya diri, (11) menjadi pribadi yang lebih easy going, (12) mendetoksifikasi diri dari media sosial, (13) memberi waktu untuk diri sendiri, (14) menjadi lebih bahagia, (15) meningkatkan metabolisme tubuh, (16) menjaga kesehatan jantung, (17) meningkatkan empati, (18) memperlancar saluran pencernaan, dan (19) meningkatkan kualitas tidur.

Secara langsung maupun tidak langsung city branding memiliki pengaruh terhadap pengambilan keputusan wisatawan yang hendak mengunjungi suatu obyek wisata daerah. Mengingat tujuannya untuk mempromosikan pariwisata di suatu daerah maka city branding harus dibuat sesuai dengan kondisi di lapangan. City branding yang baik bisa dilihat dari 2 sudut pandang, internal dan eksternal. Dari sudut pandang eksternal, city branding harus bisa memberikan rasa puas 
serta bangga bagi para wisatawan karena telah mendatangi kota tersebut. Dari sudut pandang internal, city branding harus dipercayai oleh masyarakat kawasan/kota yang bersangkutan akan bisa mendatangkan kesejahteraan bagi mereka dan city brandingnya pun harus sesuai dengan imajinasi mereka akan sebuah kota yang diharapkan. Imajinasi mereka pasti berdasarkan adat kebiasaan serta nilai-nilai luhur yang sudah mengakar kuat sebagai budaya dalam kehidupan mereka.

Kepribadian merk atau brand personality sebuah kota bisa menjadi sebuah poin pembeda dengan kota lainnya. Brand personality ini akan berkaitan dengan cara menyampaikan suatu pesan (pemasaran) tentang kota itu baik kepada publik internal maupun eksternalnya. Tetapi menentukan brand personality sebuah kota bukanlah hal yang mudah, karena itu menyangkut banyaknya orang dalam pemerintahan (yang relevan) yang menentukan kepribadian tersebut. Salah-salah bukan menunjukkan kepribadian yang terjadi, tetapi justru secara tidak langsung memperlihatkan bahwa kota tersebut tidak punya kepribadian.

Pemimpin daerah sangat berperan dalam menentukan kepribadian sebuah kota. Yananda \& Salamah (2014) menjelaskan bahwa city branding yang ada di Indonesia seharusnya terintegrasi dengan leadership branding atau juga personal branding pemimpinnya. Pemimpin disini bukan hanya pemimpin yang secara sturuktural menduduki jabatan sebagai kepala daerah, tetapi juga bisa dimaknai sebagai orang-orang yang mempunyai banyak pengikut setia dan omongannya menjadi panutan bagi para pengikutnya.

Di Bangkalan sendiri, wibawa kepala daerah atau kepala pemerintahan dinilai lebih rendah dari wibawa kyai dan ulama. Untuk diketahui, Bangkalan merupakan daerah dengan mayoritas penduduknya beragama Islam, dan Islam menjadi acuan dalam berperilaku masyarakat. Karena itu, pemuka agama Islam mempunyai kedudukan yang tinggi di masyarakat. Karena itu, ulama atau kyai lebih kredibel dibandingkan dengan kepala pemerintahan. Maka pemerintah selalu menggandeng para ulama dan kyai dalam melaksanakan kebijakannya.

Tetapi itu bukan satu-satunya cara, karena banyak faktor yang bisa dipakai untuk menentukan city branding. Ada 4 (empat) langkah proses strategi city branding (Lestari, 2016), yakni: 1) Identity, proses pengidentifikasian aset, atribut dan identitas suatu kota 2) Objective (menentukan tujuan), yaitu mendefinisikan secara jelas alasan utama city branding. 3) Communication, proses komunikasi baik secara online maupun offline dengan semua stake holder kota 4) Coherense, proses implementasi yang memastikan segala bentuk program komunikasi dari suatu kota terintegrasi, konsisten dan menyampaikan pesan yang sama.

Terlepas dari keempat tahapan tersebut, terdapat dua cara lain untuk melakukan city branding dengan membuat brand image seluruh kota yang memadukan faktor politik, ekonomi dan budaya. Cara lainnya adalah dengan mengembangkan fasilitas pariwisata sebagai langkah untuk mempromosikan pariwisata secara eksklusif (Zhou \& Wang, 2014). Banyaknya destinasi wisata religi di Bangkalan juga bisa dijadikan sebagai brand. Destinasi itu sendiri merupakan salah satu dimensi dan elemen dalam brand pariwisata. Dari hasil penelitian, diperoleh kesimpulan banyaknya elemen dalam brand pariwisata. Salah satunya adalah seperti yang dirangkum (Judisseno, 2019), yang dapat diamati pada tabel 1 . 
Tabel 1. Dimensi dan Elemen Brand Pariwisata

\begin{tabular}{|c|c|}
\hline Tokoh & Dimensi dan elemen brand pariwisata \\
\hline Hall & $\begin{array}{l}\text { Berikan strategi komunikasi yang konsisten } \\
\text { dan fokus }\end{array}$ \\
\hline Cai & $\begin{array}{l}\text { Citra positif faktor merek, nama, istilah, } \\
\text { tanda, logo, desain, simbol, slogan, kemasan, } \\
\text { atau kombinasi di atas }\end{array}$ \\
\hline Hankinson & Aset positif dan negatif, \\
\hline & $\begin{array}{l}\text { Festival, akomodasi turis, olah raga / gaya } \\
\text { hidup }\end{array}$ \\
\hline Laaksonen dkk & $\begin{array}{c}\text { Alam, industri, budaya, lingkungan binaan, } \\
\text { atmosfer }\end{array}$ \\
\hline Cheng \& Taylor & $\begin{array}{c}\text { Greennes, arsitektur bersejarah, keragaman } \\
\text { etnis dan leissure }\end{array}$ \\
\hline Herstein \&Jaffe & Aspek kependudukan, aspek fisik \\
\hline Zenker dkk & $\begin{array}{c}\text { Kesempatan kerja, alam dan rekreasi, } \\
\text { urbanitas }\end{array}$ \\
\hline Clark dkk & $\begin{array}{l}\text { Muda, energizer, nostalgia, hidup, } \\
\text { terbebaskan, kreatif, keren, cerdas, } \\
\text { terinspirasi, eklektik, bersemangat dan } \\
\text { dinamis }\end{array}$ \\
\hline Haiden \& Sevin & $\begin{array}{l}\text { Identitas merek, identitas budaya, } \\
\text { transformasi logo }\end{array}$ \\
\hline
\end{tabular}

Di Indonesia, dimensi dan elemen dari brand pariwisata sudah ditentukan dan termaktub dalam UU No. 10 tahun 2009 tentang pariwisata. Yaitu meliputi kekayaan alam, budaya, kreativitas buatan yang tercermin dalam fasilitas umum, fasilitas pariwisata, aksesibilitas dan masyarakat itu sendiri.

Dengan demikian, wisata religi sebagai kebiasaan masyarakat Bangkalan sangat mungkin diangkat menjadi salah satu identitas kota bagi Bangkalan sendiri. Dan selama ini, ziarah ke makam sudah menjadi salah satu kegiatan wisata yang berkembang dengan sendirinya, bahkan jika tidak dibangun oleh pemerintah sekalipun. Karena itu, wisata religi sangat mungkin untuk dijadikan ikon pariwisata bagi Bangkalan dan diangkat sebagai strategi city branding.

Membangun city branding berdasarkan destinasi wisata membutuhkan komunikasi yang intensif kepada masyarakat agar mereka memahami arah kebijakan pemerintahnya. Komunikasi harus dilakukan dengan pendekatan persuasif dan harus memperhatikan persyaratan sebagai berikut, (1) informasi harus sesuai dengan kondisi masyarakat baik bahasa maupun nilai-nilai budaya dalam pesan yang disampaikan, (2) informasi harus masuk akal sehingga bisa diterima masyarakat, (3) informasi harus disampaikan dengan sentuhan sosiologis, psikologis dengan melibatkan masyarakat pada pembangunan pariwisata itu sendiri (Chamdani, 2018).

Komunikasi dalam pariwisata tidak hanya dilakukan dalam pembangunan destinasinya saja, tetapi juga dilakukan untuk memperkenalkan dan memasarkan pariwisata itu sendiri. Setiap kegiatan branding pariwisata membutuhkan komunikasi pemasaran terpadu sukses dikenal masyarakat dan mendatangkan pengunjung. Pemasaran pariwisata sendiri merupakan aktivitas dan proses yang sistematis dalam rangka menyediakan, menambahkan nilai, serta mempromosikan pelbagai produk pariwisata dalam rangka memenuhi kebutuhan, keinginan, dan harapan wisatawan maupun calon wisatawan, sehingga tercipta situasi yang saling menguntungkan antara pelaku bisnis dalam industri pariwisata dengan wisatawan dan calon wisatawan (Widokarti \& Priansa, 2019). Dalam semua proses pemasaran, komunikasi selalu dibutuhkan. 


\section{METODE PENELITIAN}

Penelitian ini menggunakan desain penelitian deskriptif kualitatif. Inti dari penelitian deskriptif adalah bahwa ia tidak terlalu mementingkan makna; Sebaliknya, ini lebih berfokus pada analisis permukaan data, hanya memperhatikan proses terjadinya suatu fenomena, dan bukan pada kedalaman atau makna data. Penelitian deskriptif kualitatif pada dasarnya mengacu pada identifikasi karakteristik yang mengidentifikasi atau mendefinisikan sekelompok orang, artefak atau peristiwa (Susilo, Sugihartati, \& Arimbi, 2019). Definisi kualitatif mencakup proses konseptualisasi dan hasil dalam pengembangan skema klasifikasi (Uber, 2010).

Jenis data dalam penelitian ini merupakan produk wawancara mendalam berupa data kualitatif yaitu data berupa pernyataan verbal, pemikiran, sikap, motivasi, nilai, harapan, kebiasaan, fakta, atribut dan kesadaran beragama. pariwisata, dan kondisi destinasi wisata religi. Dan prospek pengembangan merek wisata religi. Jenis data dalam penelitian ini juga merupakan hasil observasi dari 3 tempat wisata religi yang besar dan terkenal di Bangkalan yakni makam Syaichona Cholil, Aer Mata Ebu dan makam Potre Koneng di bukit Geger.

Sumber data didapat secara primer serta sekunder. Data primer merupakan hasil wawancara dengan para stakeholder pariwisata yang ada di Madura ataupun di tempat lain yang berhubungan dengan tujuan penelitian ini. Data primer yang berupa pernyataanpernyataan, interpretasi, kegiatan serta peristiwa yang menjadi pengamatan selama kurun waktu penelitian. Data primer juga didapatkan melalui observasi serta pengamatan di destinasi wisata dan media sosial yang berkaitan dengan destinasi wisata Madura. Sementara data sekunder diperoleh dari hasilhasil penelitan terdahulu, berita dan tulisan di situs-situs internet yang relevan dengan subyek penelitian. Obyek penelitian dalam hal ini adalah brand wisata religi untuk kabupaten Bangkalan, sedangkan subyek penelitian adalah destinasi wisata religi dan stake holder yang relevan dengan wisata religi itu, seperti masyarakat setempat, kyai dan pemerintah daerah.

\section{HASIL DAN PEMBAHASAN}

Setelah dilakukan penelitian lapangan selama kurang lebih 6 (enam) bulan, kami berhasil memperoleh data dan fakta lapangan tentang kondisi destinasi wisata di kabupaten Bangkalan. Kearifan lokal Bangkalan, dimana masyarakatnya sangat relijius dan taat beragama (Islam) sangat terasa di hampir seluruh sendi kehidupan kota. Hampir di semua ruas jalan terdapat masjid, kumandang ayat suci Al-Quran juga terdengar dari masjidmasjid. Salah satu kepercayaan yang sampai saat ini masih dilakukan adalah ziarah ke makam para pendahulu/leluhur/tokohagama. Karena itu, beberapa makam tokoh agama/leluhur masyarakat Bangkalan kemudian menjadi tujuan para peziarah.

Data hasil penelitian menunjukkan terdapat beberapa makam yang tidak pernah sepi pengunjung, yaitu:

- Pasarehan Saichona Cholil

- Makam Syarifah Ambami - Aer Mata Ebu

- Situs Potre Koneng - Bukit Geger

Ketiga destinasi tersebut selalu didatangi pengunjung, dan dibuka 24 jam. Alasannya karena pengunjung yang datang tidak mengenal waktu, bahkan tengah malam sekalipun. Pengunjung tidak hanya datang dari daerah-daerah sekitar destinasi, tapi juga dari luar kota. Mereka biasanya datang dengan mengendarai bis-bis sewaan, meski pun ada juga yang datang dengan mobil pribadi dan sepeda motor. Karena itu, di sekitar destinasi sudah dibangun area parkir yang memadai.

Biasanya para pengunjung akan berziarah ke makam, menunaikan sholat dan melafalkan doa-doa. Karena itu, lokasi di dekat makam selalu ada tempat/ruangan untuk para peziarah berdoa. Bahkan, dibangun masjid di dekat makam, seperti di Paserehan Syaichona Cholil dan Sunan Cendana.

Budaya ziarah makam ini mempunyai potensi untuk dikembangkan dan dijadikan branding sebagai kota ziarah dan membangun wisata religinya. Hasil analisa, nampak dalam penjabaran berikut ini.

\section{Strength/Kekuatan}

- Sudah dikenal di Bangkalan dan sekitarnya, terutama di Madura 
- Destinasinya sudah ada, bahkan beberapa sudah dibangun fasilitasnya oleh pemerintah seperti area parkir.

- Sudah banyak pengunjung setiap harinya, berarti pangsa pasarnya sudah jelas ada.

- Sudah ada pengurusnya (seperti pengurus masjid), sehingga memungkinkan untuk diteruskan sambil dilakukan penguatan bidang manajemen (SDM, keuangan, lingkungan, dll)

- Sejalan dengan budaya dan kearifan lokal masyarakatnya

\section{Weakness/Kelemahan}

- Belum dikenal di luar masyarakat Madura, sehingga belum dikunjungi oleh masyarakat di luar Madura.

- Penokohannya terlalu lokal Madura, sehingga agak sulit diangkat menjadi tokoh yang menasional, dan menjadi tujuan ziarah masyarakat diluar Madura, seperti ziarah wali songo

- Destinasinya tidak dikelola secara profesional sehingga terkesan seadanya, kotor dan tidak mengedepankan pelayanan dan kepuasan pengunjung

\section{Opportunity/Peluang}

- Punya potensi dikembangkan dengan menambahi kegiatan-kegiatan (agenda) yang relevan dengan ziarah, kirim doa dan semacamnya

- Pasar masih bisa diperluas ke kabupatenkabupaten lain di Madura dan ke masyarakat Madura perantauan seperti masyarakat Madura yang tinggal di daerah Tapal Kuda (Banyuwangi, Jember, Situbondo, Bondowoso, Probolinggo) serta ke seluruh masyarakat Madura yang tersebar di banyak wilayah di Indonesia

- Punya potensi besar untuk juga membuka pasar UMKM pendukung pariwisata (makanan, batik, dan cenderamata lainnya)

- Perkembangan teknologi informasi dan media sosial memungkinkan untuk menyebarluaskan informasi dan promosi wisata secara mudah dan murah. Teknologi informasi juga memungkinkan mengembangkan pasar sampai ke mancanegara, apabila dilakukan dengan menarik dan kreatif.

- Revitalisasi sejarah dan legenda

\section{Threat/Ancaman}

- Perkembangan budaya populer dan teknologi informasi yang menyurutkan kebiasaan silaturahmi tatap muka menjadi silaturahmi virtual dan surutnya nilai kekerabatan sehingga masyarakat tidak lagi 'toron' atau mudik ke kampung halaman.

- Ketidaktertarikan generasi muda terhadap sejarah dan legenda akibat perubahan zaman.

Melihat potensi tersebut, sangat mungkin jika Bangkalan dibangun dengan ciri khas wisata religi. Desain ini memungkinkan dikembangkan dengan cepat karena potensinya sudah ada dan kecil kemungkinan ditolak oleh masyarakat. Adapun analisis branding untuk kota ziarah dan wisata religi bagi Bangkalan meliputi beberapa analisis.

Dari sisi segmentasi, seluruh masyarakat Madura yang tingal di Madura dan di perantauan yang menyebar ke seluruh wilayah Indonesia. Target ditujukan pada masyarakat Madura yang tinggal di Madura dan daerah Tapal Kuda. Untuk positioning lebih pada destinasi ziarah dan wisata religi, nama Brand Bangkalan sebagai Kota Ziarah. Filosofi tersebut menggambarkan bahwa masyarakat Bangkalan tidak pernah melupakan sejarah dan menghormati leluhurnya. Karena itu, ziarah ke makam leluhur adalah sebuah tradisi yang positif, dan berdampak terhadap suasana psikologis masyarakat serta memberikan kontribusi terhadap peningkatan kesejahteraan masyarakatnya. Peningkatan kesejahteraan ini bisa dirasakan tidak hanya oleh masyarakat sekitar destinasi tetapi juga masyarakat Bangkalan secara umum. Karena dengan banyaknya masyarakat yang mengunjungi Bangkalan untuk melakukan ziarah akan juga menghidupkan ekonomi masyarakat dari:

- Kuliner (Rumah makan dan PKL makanan)

- Cendera mata (pengrajin dan pedagang)

- Batik (pengrajin dan pedagang)

Selain itu, berdampak positif juga untuk:

- Melestarikan budaya dan sejarah

- Mengembangkan kearifan lokal dan kesenian bernafaskan islam

- Mendorong masyarakat untuk memelihara tempat ibadah sebaik mungkin

Dari konsep Branding menjadikan kota yang menghargai budaya dan sejarah, dan memfasilitasi masyarakat untuk tetap 
melestarikan sejarah dengan mendoakan dan mengirim doa untuk tokoh-tokoh Madura.

Aplikasi Fasilitas

- Masjid dan ruangan berdoa/kirim doa di sekitar makam

- Area parkir yang luas

- Area pusat kuliner dan cendera mata

- Fasilitas tempat wudhu dan kamar mandi yang bersih

- Terdapat pendopo/aula tempat mengadakan acara massal

- Sarana prasarana pendukung seperti jalan aspal, wifi, dan lain-lain

Aplikasi Kegiatan Agenda Wisata

- Pengajian akbar yang teragendakan setiap tahun di setiap destinasi (bergantian jadwalnya)

- Lomba-lomba kesenian religi (hadrah, musik patrol, terbangan, desain busana muslim, lomba qiroah, lomba adzan, lomba barjanji, dll) yang diagendakan setiap tahunnya dan di promosikan secara nasional

- Festival kebersihan tempat ibadah

\section{KESIMPULAN}

Konsep city branding yang jelas memang belum dipunyai, tetapi Bangkalan sesungguhnya sudah mempunyai dasar yang bisa ditonjolkan sebagai identitas kota. Kebiasaan, kesenian dan kearifan lokal masyarakatnyalah yang bisa menjadi dasar itu. Tinggal membuat konsep berdasarkan hal-hal di atas, maka sangat mungkin Bangkalan bisa mengejar ketertinggalannya di bidang pariwisata dengan kota-kota lain di sekitarnya.

Wisata religi selama ini telah berjalan dengan pengunjung yang tidak pernah terputus dari hari ke hari. Kebanyakan wisatawan datang untuk berziarah ke makam kyai dan leluhur Madura. Wisata religi ini sangat mungkin untuk menjadi primadona dan diangkat menjadi ikon Bangkalan. City branding bisa dibangun berbasis kebiasaan masyarakat melakukan ziarah dan berdoa di makam ulama/leluhur. Ini juga sejalan dengan keinginan para ulama untuk tidak meninggalkan kearifan lokal dalam membangun city branding Bangkalan.
Jika memang ingin membangun city branding dari wisata religi, maka banyak pekerjaan yang harus diselesaikan terlebih dulu, seperti mengubah mindset masyarakat tentang pariwisata, menyamakan persepsi tentang pariwisata ke semua elemen masyarakat terutama ulama dan kyai. Kesepemahaman antara pemerintah dengan ulama menjadi syarat utama keberhasilan pembangunan city branding di Bangkalan. Diperlukan komunikasi yang intens dengan pendekatan budaya, sosial dan psikologis agar masyarakat mau mendukung jika memang pemerintah menginginkan untuk membangun branding kota berdasarkan wisata religi ini.

Rasanya, mengangkat konsep wisata religi menjadi city branding Bangkalan merupakan langkah yang tepat karena selain unik, segmentasi jelas, dan yang penting adalah sesuai dengan kearifan lokal masyarakat Bangkalan.

\section{DAFTAR PUSTAKA}

Annisarizki, \& Sucahya, M. (2018). Manajemen Wisata Religius Kesultanan Banten (Bauran Komunikasi Pemasaran Dalam Meningkatkan Jumlah Wisatawan). Nyimak Journal of Communication, 2(2).

Anwar, M., Hamid, D., \& Topowijono, T. (2017). Analisis Dampak Pengembangan Wisata Religi Makam Sunan Maulana Malik Ibrahim, madalam Kehidupann Sosial Dan Ekonomi Masyarakat Sekitar (Studi Pada Kelurahan Gapurosukolilo Kabupaten Gresik). Jurnal Administrasi Bisnis, 44(1), 186-193.

Arifin, R. (2007). Zirah Wali Spiritual Sepanjang Masa. Yogyakarta: Pustaka Timur.

Chamdani, U. (2018). Komunikasi Dalam Pembangunan Destinasi Pariwisata. Yogyakarta: DeePublish.

Chotib, M. (2015). Wisata Religi di Kabupaten Jember. Jurnal Fenomena, 14(2), 206225.

Deviana, I. (2019). Ke Madura, Belum Lengkap Kalau Gak Cobain Bebek Sinjay!

Eushuis, J., \& Klijn, E. (2010). Branding in 
governance processes: a theoretical perspective. Paper for the 14th International Research Seminar of Public Management: "The Crisis: Challenges for Management”, Panel Public Branding, Bern: University of Berne.

Judisseno, R. (2019). Branding Destinasi \& Promosi Pariwisata. Gramedia pustaka utama.

Kavaratzis, M. (2004). From city marketing to city branding: Towards a theoretical framework for developing city brands. Place Branding, 1(1), 58-73.

Keller, K., Parameswaran, M., \& Jacob, I. (2011). Strategic brand management: Building, measuring, and managing brand equity. Pearson Education India.

Kumparan. (2018). Bukit Jaddih, Lokasi Wisata Instagramable Terbaru di Madura.

Lestari, R. (2016). Membangun Citra Sebuah Kota Dalam Persaingan Global Melalui City Branding. Jurnal Ilmiah STIE MDP, $5(2), 68-79$.

Prabowo, D. (2018). Sejarah Jembatan Suramadu, dari Soekarno hingga Jokowi.

Rachmad, T. (2017). Strategi branding wisata syariah pulau madura. Commed: Jurnal Komunikasi Dan Media, 1(2), 121-141.

Rafa'al, M. (2017). Gaya Komunikasi Pemasaran di Pemerintah: Promotion Mix Destinasi Tujuan Wisata Kabupaten Raja Ampat. Jurnal Studi Komunikasi. https://doi.org/10.25139/jsk.v1i1.63

Ratman, D. (2016). Rapat Koordinasi Nasional Kementerian Pariwisata.

Riyadi, S., Susilo, D., Armawati Sufa, S., \& Dwi Putranto, T. (2019). Digital marketing strategies to boost tourism economy: a case study of atlantis land surabaya. Humanities \& Social Sciences Reviews, $\quad 7(5), \quad$ 468-473. https://doi.org/10.18510/hssr.2019.7553

Sari, M. (2016). 19 Manfaat Wisata Religi Yang Wajib Diketahui.

SNC. (2020). Peta Bangkalan Lengkap 18 Kecamatan.

Susilo, D., \& Primatama, M. (2018). City Architecture as the Production of Urban Culture: Semiotics Review for Cultural Studies. Jurnal Humaniora. https://doi.org/10.22146/jh.v30i3.29117

Susilo, D., Putranto, T. D., Neu, M. T. L. M.,
\& Navarro, C. J. S. (2020). Nagekeo women's cultural struggle as a flores subculture against the flow of civilization's progress. Bricolage: Jurnal Magister Ilmu Komunikasi, 6(01), 001. https://doi.org/10.30813/bricolage.v6i01. 2064

Susilo, D., Sugihartati, R., \& Arimbi, D. A. (2019). Indonesian Women in Politics: Critical Analysis of Portrayal in Online News Sites. Jurnal ILMU KOMUNIKASI, $16(2), \quad 225$. https://doi.org/10.24002/jik.v16i2.1477

Syam, N. (2005). Islam pesisir. LKiS Pelangi Aksara.

Uber, S. (2010). Metodologi Penelitian Sosial. Bandung: Rafika Aditama.

Widokarti, J., \& Priansa, D. (2019). Komunikasi Pemasaran Terpadu Dalam Industi Pariwisata. Bandung: Alfabeta.

Winarti, O. (2017). Halal Tourism in Indonesia: Does it attract only Muslim Tourists? Jurnal Studi Komunikasi, 1(3), 232-239.

Yananda, M., \& Salamah, U. (2014). Branding tempat: membangun kota, kabupaten, dan provinsi berbasis identitas. Makna Informasi.

Yurisma, D., \& Bahruddin, M. (2020). Pemaknaan simbol reog ponorogo dalam tradisi jawa: sebuah kajian kritis. Bricolage: Jurnal Magister Ilmu Komunikasi. https://doi.org/10.30813/bricolage.v6i01. 2070

Zhou, L., \& Wang, T. (2014). Social media: A new vehicle for city marketing in China. Cities, 37, 27-32. 
